\title{
Feasibility Evaluation of Briquette Biomass Cook Stove for Rural Area
}

\author{
S.R. Patil*, S.R. Kalbande and V.P. Khambalkar \\ Department of Unconventional Energy Sources and Electrical Engineering, Dr. Panjabrao \\ Deshmukh Krishi Vidyapeeth, Akola, MS-444 104, India \\ *Corresponding author
}

\begin{tabular}{|c|c|}
\hline \multicolumn{2}{|c|}{ A B S T R A C T } \\
\hline & 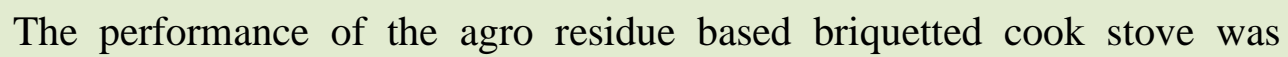 \\
\hline Keywords & carried out with agro residue briquette and solid wood. Thermal efficiency \\
\hline $\begin{array}{l}\text { Biomass, Briquette, } \\
\text { Wood, Community } \\
\text { stove and Thermal } \\
\text { efficiency. }\end{array}$ & $\begin{array}{l}\text { of cook stove was determined by conducting water boiling test. The thermal } \\
\text { efficiency of cook stove on burning briquettes was } 37 \% \text { found } 6.33 \% \\
\text { more than solid wood fuel at the corresponding highest flame temperature }\end{array}$ \\
\hline Article Info & Thermal efficiency on burning of briquette with grate height adjustment \\
\hline $\begin{array}{l}\text { Accepted: } \\
\text { 26 September } 2017 \\
\text { Available Online: } \\
10 \text { October } 2017\end{array}$ & $\begin{array}{l}\text { and without grate height adjustment was found to be } 35.42 \% \text { and } 33.23 \% \\
\text { which was } 6.18 \% \text { higher than without grate height adjustment. The } \\
\text { estimated cost of the system was Rs. } 12000 /- \text { with } 2 \text { year and } 1 \text { month } \\
\text { payback period and benefit cost ratio was found as } 1.28 \text {. }\end{array}$ \\
\hline
\end{tabular}

\section{Introduction}

Community cooking normally refers to cooking of food for a group of about 25 or more persons in hostels, schools, community centers, hotels, rural/semi urban restaurants and road side dhabas, places of worship, residential monasteries, ashrams, caterers, suppliers of mid-day meals for schools etc. Community cooking is done using a coalbased traditional oven/furnace (bhatti) and direct burning of wood in ovens. Recently the use of LPG-based burners has also become a common practice in India. It is obvious that the use of a biomass gasifier based system for community cooking may provide an overall efficiency of about 40 per cent as compared to 8 to 20 percent from traditional oven/furnace, etc. Biomass gasifier based community cooking systems are available in the thermal rating of 17.5 to $291 \mathrm{~kW}$ [1]. The use of the community stove will be for much longer time at a stretch as compared to the domestic stoves which have much shorter cooking cycles. Fuel uses for community cook stove are big logs, small twigs, processed fuel (briquettes or chopped wood).

Stove may be forced draught or natural draught based; they may be fixed or portable etc. Agro residues are being used for briquetting which is also called as white coke [2]. The surplus agro residues are being used for densification in binderless briquetting 
processes. In Akola District, more than 15 biomass briquetting plants are in operation which utilizes variety of agro residue for briquetting viz. soybean straw, ground nut shells, pigeon pea etc. For community cooking large size biomass gasifier based cook stove operating on biomass briquette could replace conventional use of wood and LPG. Hence in order to replace conventional fuel it is essential to design and develop a gasifier based cook stove based on agro residue briquettes [3].

\section{Materials and Methods}

\section{Performance evaluation of biomass cook stove}

The performance of the agro residue based briquetted cook stove has been tested according to IS 13152 (Part 1). The performance of agro residue briquette cook stove tested with agro residue (soybean) briquette (Fig. 1) and solid wood (Fig. 2).

Efficiency of cook stove was determined by carried out standard water boiling test [4]. During test various parameters such as flame temperature, outside stove temperature, remaining ash, gas outlet temperature and water temperature were measured (Fig. 2). The following parameters were measured during the performance evaluation of the biomass cook stove (Fig. 3).

\section{Flame temperature}

The flame temperature of burning gas was measured by using thermocouple attached with temperature indicator

\section{Outside stove temperature}

The outside temperature of stoves was measured with the help of non-contacting thermometer.

\section{Air outlet temperature}

The air outlet temperature was measured by using thermocouple attached with temperature indicator.

\section{Ash}

After total burning of biomass the remaining ash were weighed by using weigh balance.

\section{Thermal Efficiency}

The thermal efficiency of a biomass cook stove indicated how well that stove could transfer the energy content in the fuel to the cooking pot [5, $6 \& 7]$.

\section{Determination of burning capacity rate}

The fuel burning rate of the designed cook stove was estimated according to BIS test code IS 13152 (Part 1) as follows [4, 5, 8, 9];

The fuel was stacked in a honey comb fashion in combustion chamber up to 3/4 of the height of the combustion chamber.

Weight the cook stove with fuel was taken, and noted as M1 kg.

$10 \mathrm{ml}$ of kerosene was sprinkled on the fuel from the top of cook stove.

The time of complete combustion that is up to the last flame was noted down as T minutes.

Then the cook stove with residue was weighed and noted as M2 kg.

Then the burning capacity of the cook stove as heat input per hour was calculated as follows:

Heat input per hour $=$ B.R. $\times$ CVf $(1)$ 
Burning rate $($ B.R. $)=\{(\mathrm{M} 1-\mathrm{M} 2) / \mathrm{T}\} \times 100$ (2)

Where,

M1 = The initial mass of the cook stove with test fuel in $\mathrm{kg}$,

M2 = The mass of the cook stove with fuel residues, after burning the test fuel for particular time $(\mathrm{T})$ minutes in $\mathrm{kg}$.

CVf $=$ Calorific value of the test fuel in $\mathrm{kcal} / \mathrm{kg}$.

\section{Procedure carried out for thermal efficiency test}

The size of the vessel and the quantity of water was taken for the thermal efficiency test was selected according to IS 13152 (Part 1), $[5,7,8,10]$;

The thermal efficiency and the emission test were carried out without adding any additional fuel. The test was repeated and the average was taken.

For the designed cook stove the test fuel was taken as per burning capacity rate of the cook stove for an hour.

Then the test fuel was divided into 6 equal lots. Its mass was noted as EI.

The first lot of the test fuel was stacked in honey comb fashion in the combustion chamber.

Then the vessel was put with lid and stirrer.

$10 \mathrm{ml}$ kerosene was sprinkled for easy ignition of the test fuel.

Feeding of fresh test fuel lot was done after every 6 minutes.
The water in the vessel was allowed to warm steadily till it reached a temperature of about $90{ }^{\circ} \mathrm{C}$, then stirring was commenced and continued until the temperature of water reached $95{ }^{\circ} \mathrm{C}$. Then, time taken to heat the water from initial temperature $\mathrm{T} 1$ to the final temperature $\mathrm{T} 2{ }^{\circ} \mathrm{C}$ was noted.

Then the vessel was removed from the cook stove and the second vessel was put immediately on the cook stove. The first vessel was prepared immediately for subsequent heating.

The experiment was repeated alternatively by putting $\mathrm{N}$ vessels till there was no visible flame in the combustion chamber of the cook stove. The temperature of the water in the last vessel was noted as $\mathrm{T} 3{ }^{\circ} \mathrm{C}$ (Fig. 1)

$\eta=\frac{m_{w i} c_{p w}\left(T_{e}-T_{i}\right)+m_{i} \text {, evap }_{f} \lambda_{f}}{m_{f} C V_{f}}$

Where,

$\mathrm{m}_{\mathrm{wi}}$ - Mass of water initially, $\mathrm{kg}$

$\mathrm{c}_{\mathrm{pw}}$ - Specific heat of water, $\mathrm{kcal} / \mathrm{kg}{ }^{\circ} \mathrm{C}$

$\mathrm{T}_{\mathrm{e}}$ - Temperature of boiling water, ${ }^{\circ} \mathrm{C}$

$\mathrm{T}_{\mathrm{i}}$ - Initial temperature of water, ${ }^{\circ} \mathrm{C}$

$\mathrm{m}_{\mathrm{i}}$, evap - Mass of water evaporated, $\mathrm{kg}$

$\lambda f-$ Latent heat of vaporization of water, 589 $\mathrm{kcal} / \mathrm{kg}$

$\mathrm{m}_{\mathrm{f}}$ - Mass of fuel burned, $\mathrm{kg}$

$\mathrm{CVf}-$ Calorific value of fuel, $\mathrm{kcal} / \mathrm{kg}$

\section{Power output rating}

The power output is the amount of energy produced by the system in $\mathrm{kW}$. Power output can be calculated by using formula $[6,7,8$, $10,11]$

$P=\frac{F \times C V \times \Pi}{860 \times 100}(4)$ 
Where,

$\mathrm{F}=$ Burning rate, in $\mathrm{kg} / \mathrm{hr}$

$\mathrm{CV}=$ Calorific value of fuel, in $\mathrm{kcal} / \mathrm{kg}$

$\eta=$ Thermal efficiency of stove, $\%$

\section{Controlled Cooking Test (CCT)}

This is a field test used to evaluate the stove performance of a new cook stove under the common or traditional cooking methods [12, 13]. CCT is designed to compare the different cook stove's performance in a controlled manner by controlling fuels, pots, and operation of the stove. Local users prepare a traditional food on the stoves, so that stoves can be compared, by cooking the same food in the same pot and give their opinions for modification in the cook stove model. It reveals what is possible in households under ideal conditions. The CCT stimulates the actual cooking, when the stove subjected to more realistic through controlled conditions. The test was performed for evaluating the following aspects regarding the cook stove; (i) to compare the amount of fuel used by different cook stoves to cook a food or meal, (ii) to compare the time needed to cook that food (Fig. 2).

\section{Emission Test}

The emission from the smoke of cook stove consisted of determination of carbon monoxide (CO), nitrogen oxide $\left(\mathrm{NO}_{\mathrm{x}}\right)$, sulphur oxide $\left(\mathrm{SO}_{\mathrm{x}}\right)$, carbon dioxide $\left(\mathrm{CO}_{2}\right)$, and hydrocarbon $(\mathrm{HC})$ etc. The emission characteristics were carried out with the help of gas analyzer (Fig. 3). Emission analysis carried out at Anacon laboratory pvt. Ltd., Nagpur $[14,15]$.

\section{Results and Discussion}

The community sized agro residue based briquetted cook stove was fabricated in the workshop of the department. The designed system was tested for its technical as well as economic feasibility for community cooking. The data was collected during the water boiling test and emission testing. The data were observed along with parameters such as initial temperature of water, hot water temperature and ash remaining. Moisture content, proximate analysis in which fixed carbon, volatile matter and ash content were determined. Physical properties of biomass briquettes were determined such as overall length and diameter of briquettes, bulk density, shatter resistance and resistance to water penetration. Flame temperature, flue gas outlet temperature, stove surface temperature, burning rate, power output rating, emission characteristics and thermal efficiency were determined.

\section{Performance evaluation of agro residue based briquette cook stove}

The performance of biomass briquette cook stove was carried out for soybean briquette in the department laboratory. The performance test has been carried out according to BIS test code IS 13152 (Part 1). The evaluation of cook stove has been worked out for the various parameters; the standard water boiling test was carried out to know the performance level and heat utilized during the operation, temperature profile of cook stove, emission analysis of smoke, burning rate of stove, thermal efficiency, remaining ash and power output rating were recorded during the test.

\section{Temperature profile of community cook stove}

The temperature performance of community cook stove has been determined for different feed stock.

\section{Water temperature}

In the table 1 , temperature of water in pot was measured with and without grate height 
adjustment with briquette and subabul used as feedstock. It was found that burning with subabul water temperature rises faster as compared to briquettes. But in both feedstock with grate height adjustment water temperature rising was faster.

In figures 1 and 2 various temperatures of cook stove were recorded with grate height adjustment and without grate height adjustment with burning of briquettes and subabul wood. Temperature gain with burning of subabul was faster rate and slower rate with burning of briquettes. It was observed that with using grate height adjustment temperature gain was faster in burning of subabul wood as well as in briquettes.

\section{Flame temperature}

The flame temperatures of cook stove were recorded with grate height adjustment and without grate height adjustment with burning of briquettes and subabul wood (Fig. 3).

Highest temperature was recorded using subabul as fuel with grate height adjustment i.e. $730.2^{\circ} \mathrm{C}$. but flame off in $45 \mathrm{~min}$ whereas burning of briquette provided 55 min of flame and highest temperature attained was $662.3^{\circ} \mathrm{C}$ as depicted in table 2 (Fig. 4).

\section{Surface temperature of cook stove}

Surface temperature of cook stove was recorded at top, middle and bottom to know the amount of heat dissipates through conduction and the user safety. It was well below the safety limit of $60{ }^{0} \mathrm{C}$ due to the insulation provided at top, middle and bottom of community cook stove.

Various surface temperatures of cook stove were recorded from top, middle and bottom of cook stove with time (Fig. 5). The highest temperature at top of was $58.1{ }^{0} \mathrm{C}$ at middle was $51.3{ }^{\circ} \mathrm{C}$ and at bottom was $46.2{ }^{\circ} \mathrm{C}$. As depicted in table 3 .

\section{Flue gas outlet temperature}

It was the temperature recorded at the outlet of chimney. The highest temperature recorded through burning of subabul wood was 370.9 ${ }^{0} \mathrm{C}$ and through burning of briquettes was $350.2{ }^{\circ} \mathrm{C}$ as depicted in table 4 .

Table.1 Effect of grate height adjustment on water temperature

\begin{tabular}{|c|c|c|c|c|c|}
\hline \multirow{2}{*}{ SN } & \multirow{2}{*}{$\begin{array}{l}\text { Time, } \\
\text { min. }\end{array}$} & \multicolumn{2}{|c|}{$\begin{array}{c}\text { Temp. without grate height } \\
\text { adjustment, }{ }^{\circ} \mathbf{C}\end{array}$} & \multicolumn{2}{c|}{$\begin{array}{c}\text { Temp. with grate Height } \\
\text { adjustment, }{ }^{\circ} \mathbf{C}\end{array}$} \\
\cline { 3 - 6 } & & Briquette & Subabul & Briquette & Subabul \\
\hline 1 & 0 & 29 & 29 & 29 & 29 \\
\hline 2 & 5 & 33.4 & 30 & 31.2 & 33.1 \\
\hline 3 & 10 & 49.8 & 41.5 & 44.5 & 46.3 \\
\hline 4 & 15 & 46.5 & 53.3 & 51.1 & 61.5 \\
\hline 5 & 20 & 55.6 & 68.2 & 64.8 & 78.2 \\
\hline 6 & 25 & 68.2 & 82.4 & 77.5 & 95.7 \\
\hline 7 & 30 & 79.1 & 98.6 & 83.2 & 100 \\
\hline 8 & 35 & 91.3 & 100 & 95.2 & 100 \\
\hline 9 & 40 & 100 & 100 & 100 & 100 \\
\hline 10 & 45 & 100 & 99.9 & 100 & 100 \\
\hline 11 & 50 & 99.3 & 99.2 & 100 & 99.2 \\
\hline 12 & 55 & 98.9 & 98 & 99.3 & 98.8 \\
\hline 13 & 60 & 97.8 & 97.7 & 98 & 98.2 \\
\hline
\end{tabular}


Table.2 Effect of grate height on flame temperature

\begin{tabular}{|c|c|c|c|c|c|}
\hline \multirow{2}{*}{ SN } & \multirow{2}{*}{$\begin{array}{l}\text { Time, } \\
\text { min. }\end{array}$} & \multicolumn{2}{|c|}{$\begin{array}{r}\text { Temp. without grate height } \\
\text { adjustment, }{ }^{\circ} \text { C }\end{array}$} & \multicolumn{2}{|c|}{$\begin{array}{r}\text { Temp. with grate Height } \\
\text { adjustment, }{ }^{\circ} \text { C }\end{array}$} \\
\cline { 3 - 6 } & & Briquette & Subabul & Briquette & Subabul \\
\hline 1 & 0 & - & - & - & - \\
\hline 2 & 5 & 284.7 & 282.3 & 294.2 & 290.3 \\
\hline 3 & 10 & 358.3 & 379.2 & 385.6 & 387.9 \\
\hline 4 & 15 & 456.3 & 497.1 & 472.3 & 492.8 \\
\hline 5 & 20 & 517.3 & 587.8 & 526.4 & 582.7 \\
\hline 6 & 25 & 572.1 & 657.2 & 570.3 & 660.3 \\
\hline 7 & 30 & 616.5 & 680.4 & 610.9 & 730.2 \\
\hline 8 & 35 & 590.3 & 520.5 & 662.3 & 690.4 \\
\hline 9 & 40 & 434.4 & 445.8 & 647.4 & 520.3 \\
\hline 10 & 45 & 312.13 & 317.6 & 610.3 & 390.7 \\
\hline 11 & 50 & - & - & 530.2 & 357.2 \\
\hline 12 & 55 & - & - & 445.4 & - \\
\hline 13 & 60 & - & - & - & - \\
\hline
\end{tabular}

Table.3 Surface temperature of community cook stove

\begin{tabular}{|c|c|c|c|c|}
\hline \multirow{2}{*}{ SN } & \multirow{2}{*}{ Time, min. } & \multicolumn{3}{|c|}{ Temp. using agro residue briquette, ${ }^{\circ} \mathbf{C}$} \\
\cline { 2 - 5 } & & Top & Middle & Bottom \\
\hline 1 & 0 & 36 & 36 & 36 \\
\hline 2 & 5 & 36.3 & 37.2 & 36.6 \\
\hline 3 & 10 & 44.2 & 37.9 & 37.8 \\
\hline 4 & 15 & 45.1 & 39.4 & 39.2 \\
\hline 5 & 20 & 47.2 & 42.8 & 42.4 \\
\hline 6 & 25 & 50.3 & 44.5 & 44.8 \\
\hline 7 & 30 & 55.6 & 45.7 & 45.9 \\
\hline 8 & 35 & 55.2 & 51.3 & 46.2 \\
\hline 9 & 40 & 58.1 & 51.1 & 44.8 \\
\hline 10 & 45 & 53.4 & 48.2 & 44.1 \\
\hline 11 & 50 & 55.6 & 46.9 & 42.7 \\
\hline 12 & 55 & 54.8 & 46.2 & 40.9 \\
\hline 13 & 60 & 51.4 & & \\
\hline
\end{tabular}


Table.4 Flue gas outlet temperature using briquette and subabul with grate height adjustment

\begin{tabular}{|c|c|c|c|}
\hline \multirow{2}{*}{ SN } & Time, min. & \multicolumn{2}{|c|}{ Temp. with grate Height adjustment, ${ }^{\mathbf{0}}$} \\
\cline { 2 - 4 } & & Briquette & Subabul \\
\hline 1 & 0 & & 98.2 \\
\hline 2 & 5 & 61.4 & 230.5 \\
\hline 3 & 10 & 217.5 & 280.5 \\
\hline 4 & 15 & 270.5 & 350.8 \\
\hline 5 & 20 & 332.6 & 350.9 \\
\hline 6 & 25 & 340.5 & 370.9 \\
\hline 7 & 30 & 345.6 & 361.3 \\
\hline 8 & 35 & 350.2 & 350.4 \\
\hline 9 & 40 & 348.2 & 345.5 \\
\hline 10 & 45 & 336.2 & 333.5 \\
\hline 11 & 50 & 320.6 & 320.5 \\
\hline 12 & 55 & 309.5 & 295.6 \\
\hline 13 & 60 & 285.2 & \\
\hline
\end{tabular}

Table.5 Power rating of community cook stove

\begin{tabular}{|c|c|c|c|c|}
\hline SN & Biomass feedstock & $\begin{array}{l}\text { Burning } \\
\text { rate, } \mathbf{k g} / \mathbf{h}\end{array}$ & $\begin{array}{l}\text { Ash remaining, } \\
\text { \% }\end{array}$ & $\begin{array}{l}\text { Power } \\
\text { output, } \mathbf{k W}\end{array}$ \\
\hline 1 & Briquette & 2.5 & 6.5 & 4.27 \\
\hline 2 & Solid wood (subabul) & 3.03 & 4.82 & 4.69 \\
\hline & Average & 2.76 & 5.66 & 4.48 \\
\hline
\end{tabular}

Table.6 Comparison of different cook stoves with agro residue briquette as fuel (with top rest)

\begin{tabular}{|c|l|c|c|}
\hline SN & Particulars & \multicolumn{2}{|c|}{ Values } \\
\hline 1 & Type of cook stove & $\begin{array}{c}\text { Jwalla } 99 \\
\text { ARBI }\end{array}$ & $\begin{array}{c}\text { Developed briquetted } \\
\text { cook stove }\end{array}$ \\
\hline 2 & Weight of fuel, kg & 3 & 3 \\
\hline 3 & Calorific value of fuel, $\mathrm{kcal} / \mathrm{kg}$ & 4170 & 4170 \\
\hline 4 & ${\text { Initial water temperature, }{ }^{0} \mathrm{C}}^{0} \mathrm{C}$ & 29 & 31 \\
\hline 5 & ${\text { Boiling water temperature, }{ }^{\circ}}^{\mathrm{C}}$ & 96 & 96 \\
\hline 6 & Weight of pot $1, \mathrm{~kg}$ & 2.960 & 2.960 \\
\hline 7 & Weight of pot $2, \mathrm{~kg}$ & 2.675 & 2.675 \\
\hline 8 & Weight of water + pot $1, \mathrm{~kg}$ & 27.960 & 27.960 \\
\hline 9 & Weight of water + pot $2, \mathrm{~kg}$ & 27.675 & 27.675 \\
\hline 10 & Final weight of water + pot $1, \mathrm{~kg}$ & 27.870 & 27.850 \\
\hline 11 & Final weight of water + pot $2, \mathrm{~kg}$ & 27.560 & 27.495 \\
\hline 12 & Weight of water evaporated in pot $1, \mathrm{~kg}$ & 0.090 & 0.110 \\
\hline 13 & Weight of water evaporated in pot $2, \mathrm{~kg}$ & 0.115 & 0.180 \\
\hline 14 & Temp. attained in last pot, ${ }^{0} \mathrm{C}$ & 45 & 70 \\
\hline 15 & Wt. of water evaporated last pot, $\mathrm{kg}$ & 0.030 & 0.060 \\
\hline 16 & Thermal efficiency, $\%$ & 31.08 & 35.42 \\
\hline
\end{tabular}


Table.7 Comparison of different fuel with developed briquetted cook stove without top rest

\begin{tabular}{|c|l|c|c|}
\hline SN & \multicolumn{1}{|c|}{ Particulars } & \multicolumn{2}{|c|}{ Values } \\
\hline 1 & Type of feedstock & $\begin{array}{c}\text { Agro residue } \\
\text { briquette }\end{array}$ & $\begin{array}{c}\text { Biomass wood } \\
\text { (subabul) }\end{array}$ \\
\hline 2 & Weight of fuel, $\mathrm{kg}$ & 3 & 3 \\
\hline 3 & Calorific value of fuel, kcal/kg & 4170 & 3700 \\
\hline 4 & Initial water temperature, ${ }^{0} \mathrm{C}$ & 29 & 31 \\
\hline 5 & ${\text { Boiling water temperature, }{ }^{0} \mathrm{C}}^{\mathrm{C}}$ & 96 & 96 \\
\hline 6 & Weight of pot $1, \mathrm{~kg}$ & 2.960 & 2.960 \\
\hline 7 & Weight of pot $2, \mathrm{~kg}$ & 2.675 & 2.675 \\
\hline 8 & Weight of water + pot $1, \mathrm{~kg}$ & 27.960 & 33.960 \\
\hline 9 & Weight of water + pot $2, \mathrm{~kg}$ & 27.675 & 33.675 \\
\hline 10 & Final weight of water + pot $1, \mathrm{~kg}$ & 27.855 & 33.880 \\
\hline 11 & Final weight of water + pot $2, \mathrm{~kg}$ & 27.525 & 33.585 \\
\hline 12 & Weight of water evaporated in pot $1, \mathrm{~kg}$ & 0.105 & 0.080 \\
\hline 13 & Weight of water evaporated in pot $2, \mathrm{~kg}$ & 0.150 & 0.090 \\
\hline 14 & Temp. attained in last pot, ${ }^{0} \mathrm{C}$ & 75 & 65 \\
\hline 15 & Wt. of water evaporated last pot, $\mathrm{kg}$ & 0.080 & 0.035 \\
\hline 16 & Thermal efficiency, $\%$ & 37.54 & 35.16 \\
\hline
\end{tabular}

Table.8 Comparison of cook stove with and without grate height adjustment

\begin{tabular}{|c|c|c|c|}
\hline SN & Particulars & \multicolumn{2}{|c|}{ Values } \\
\hline 1 & Type of feedstock & Briquette HA & Briquette \\
\hline 2 & Weight of fuel, $\mathrm{kg}$ & 3 & 3 \\
\hline 3 & Calorific value of fuel, $\mathrm{kcal} / \mathrm{kg}$ & 4170 & 4170 \\
\hline 4 & Initial water temperature, ${ }^{0} \mathrm{C}$ & 31 & 28.5 \\
\hline 5 & Boiling water temperature, ${ }^{0} \mathrm{C}$ & 96 & 96 \\
\hline 6 & Weight of pot $1, \mathrm{~kg}$ & 2.960 & 2.960 \\
\hline 7 & Weight of pot $2, \mathrm{~kg}$ & 2.675 & 2.675 \\
\hline 8 & Weight of water + pot $1, \mathrm{~kg}$ & 27.960 & 27.960 \\
\hline 9 & Weight of water + pot $2, \mathrm{~kg}$ & 27.675 & 27.675 \\
\hline 10 & Final weight of water + pot $1, \mathrm{~kg}$ & 27.850 & 27.890 \\
\hline 11 & Final weight of water $+\operatorname{pot} 2, \mathrm{~kg}$ & 27.495 & 27.565 \\
\hline 12 & Weight of water evaporated in pot $1, \mathrm{~kg}$ & 0.110 & 0.070 \\
\hline 13 & Weight of water evaporated in pot $2, \mathrm{~kg}$ & 0.180 & 0.110 \\
\hline 14 & Temp. attained in last pot, ${ }^{0} \mathrm{C}$ & 70 & 55 \\
\hline 15 & Wt. of water evaporated last pot, $\mathrm{kg}$ & 0.060 & 0.025 \\
\hline 16 & Thermal efficiency, $\%$ & 35.42 & 33.23 \\
\hline
\end{tabular}


Fig.1 Determination of thermal efficiency in laboratory

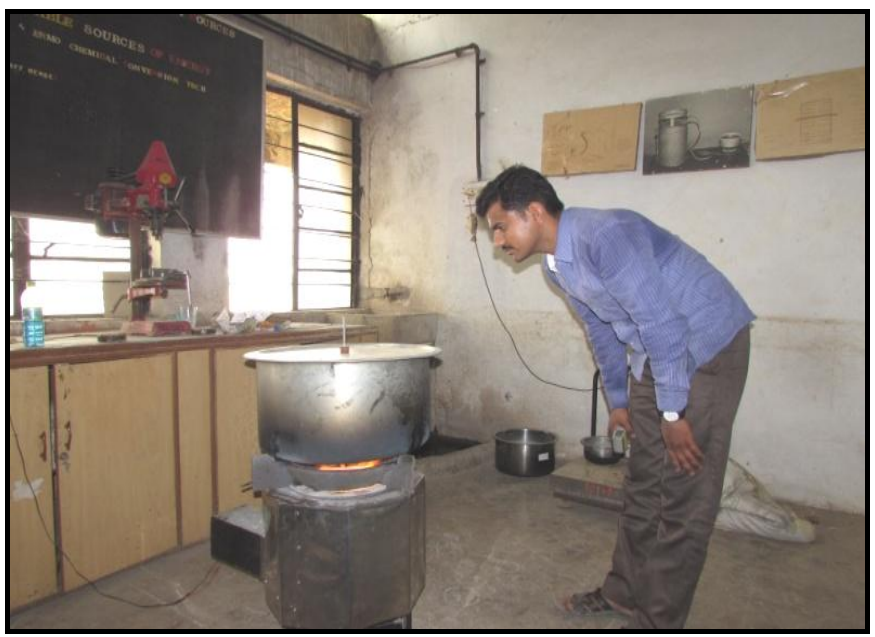

Fig.2 Controlled cooking test at boys hostel kitchen

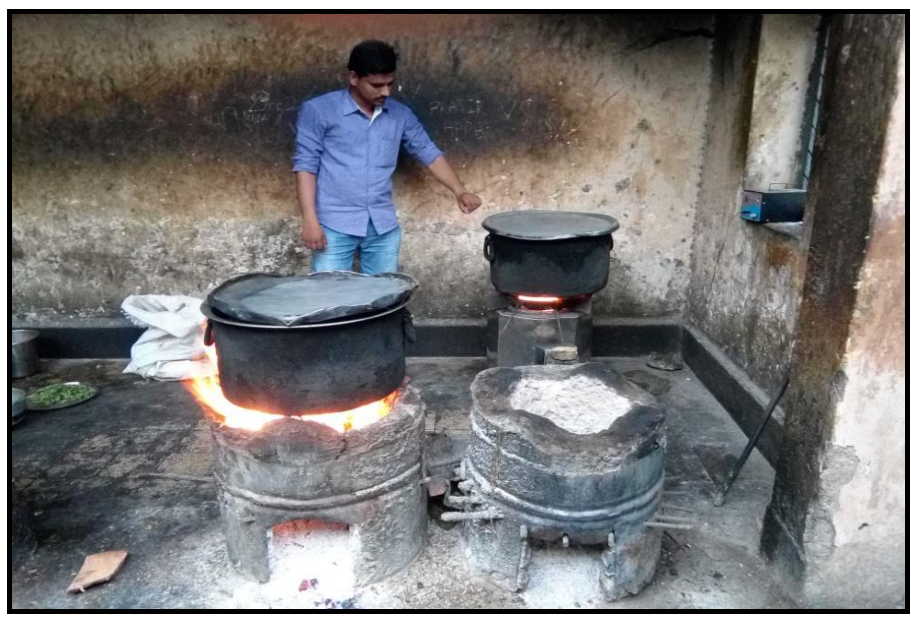

Fig.3 Smoke analysis of the developed cook stove

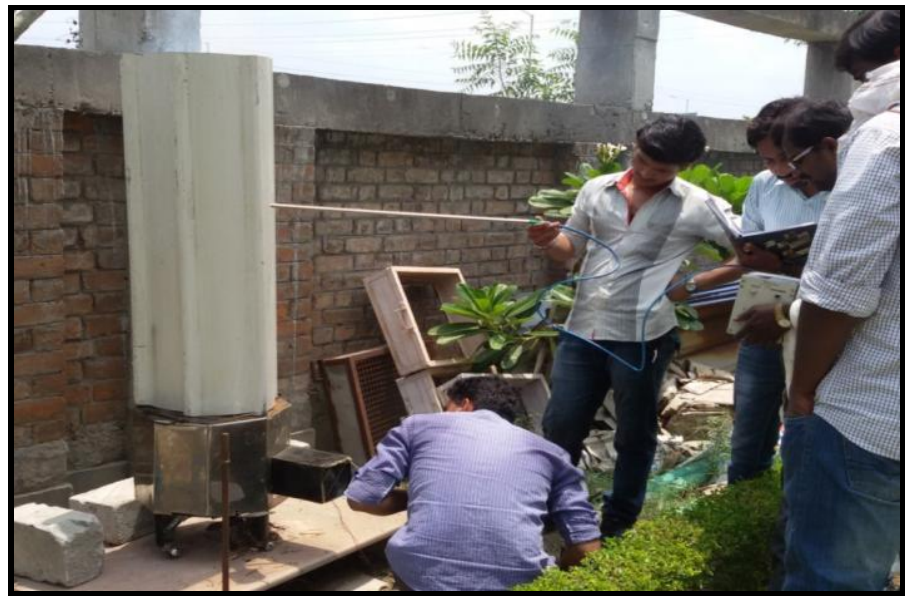


Fig.4 Variation of water temperature using briquette fuel with and without grate height adjustment

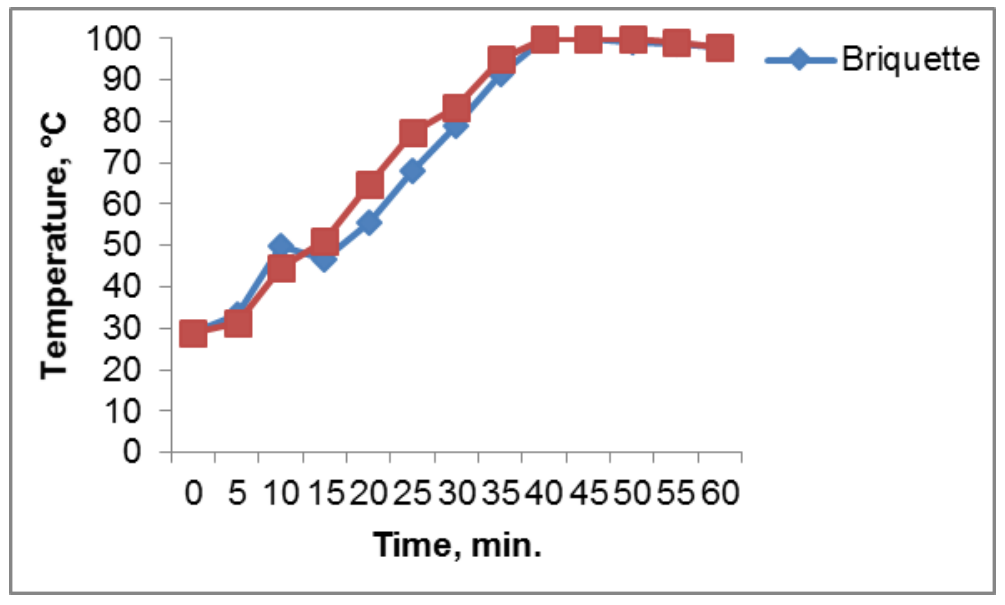

Fig.5 Variation of water temperature using subabul fuel with and without grate height adjustment

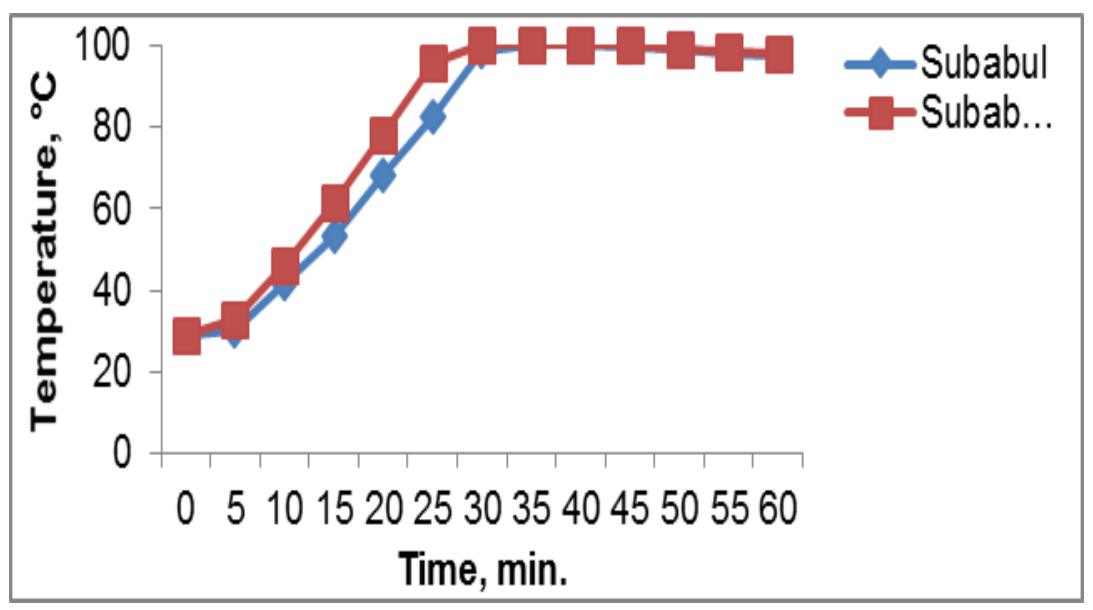

Fig.6 Variation of flame temperature using different grate height adjustment

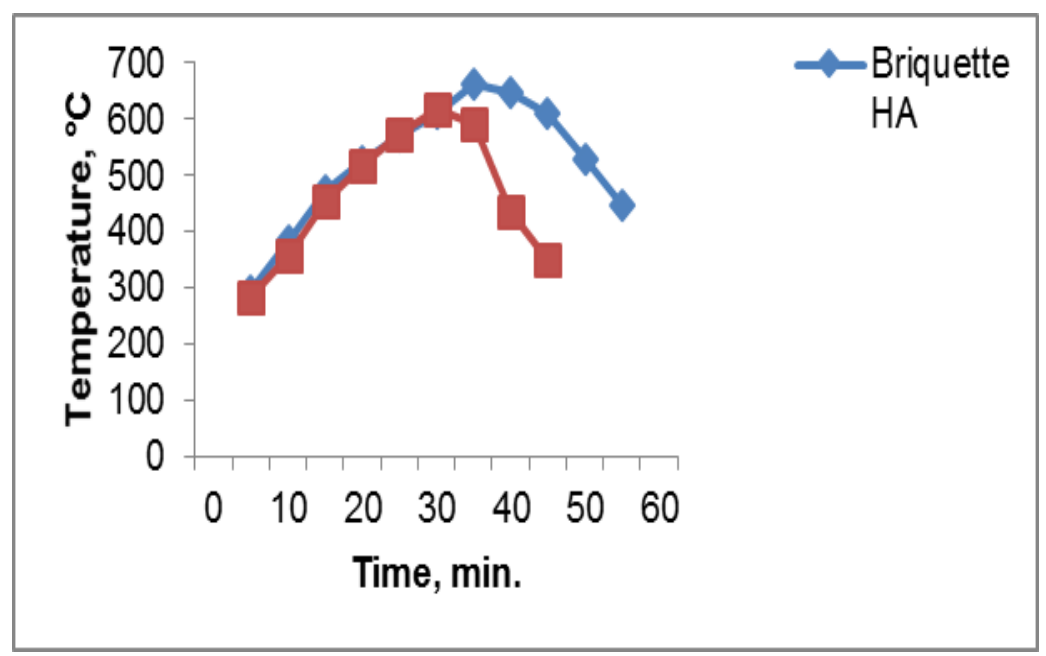


Fig.7 Variation of flame temperature using different grate height adjustment

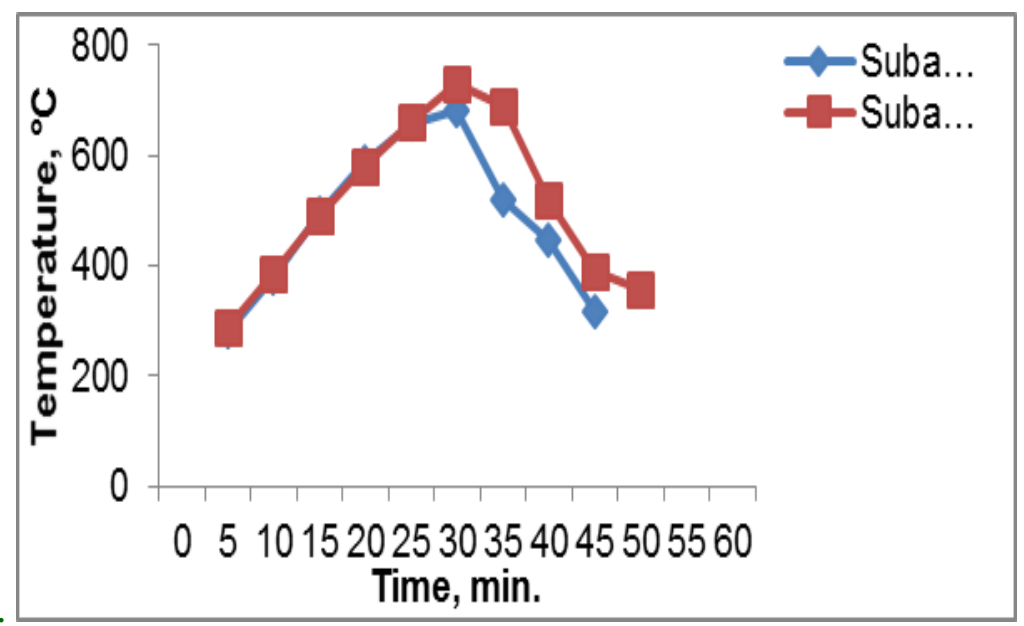

Fig.8 Surface temperature of cook stove at top, middle and bottom

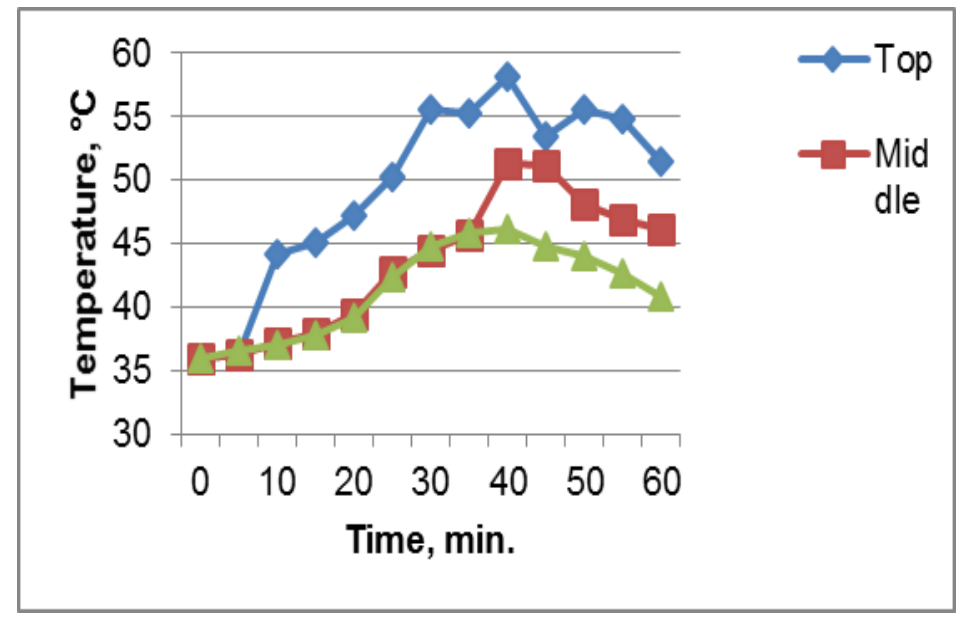

Fig.9 SOx and NOx emissions from briquetted cook stove

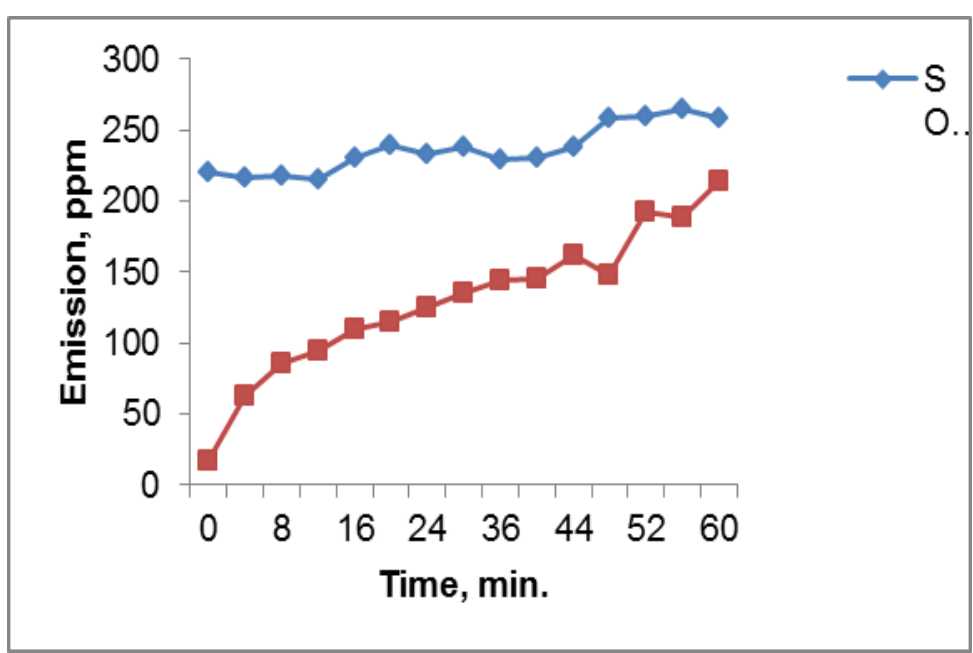


Fig.10 CO and $\mathrm{HC}$ emissions from briquetted cook stove

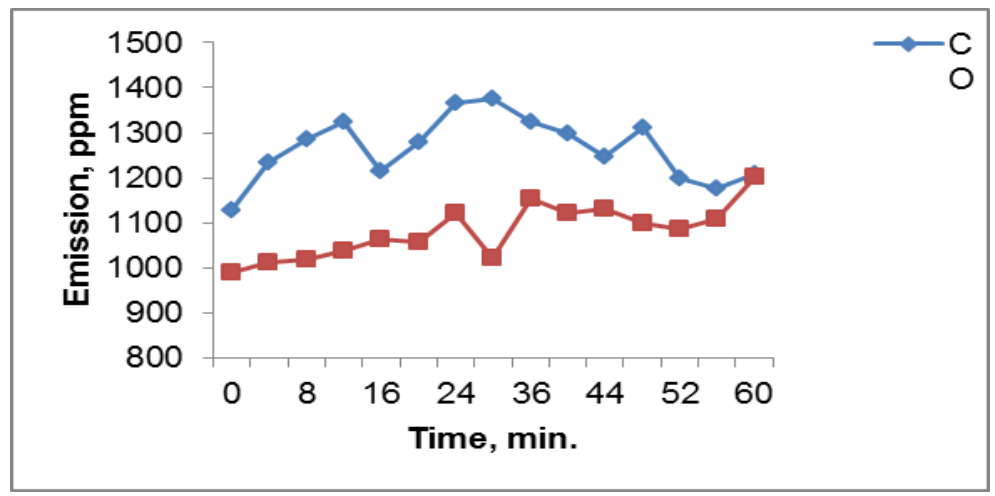

Fig.11 Emission of $\mathrm{CO}_{2}$ from briquetted cook stove

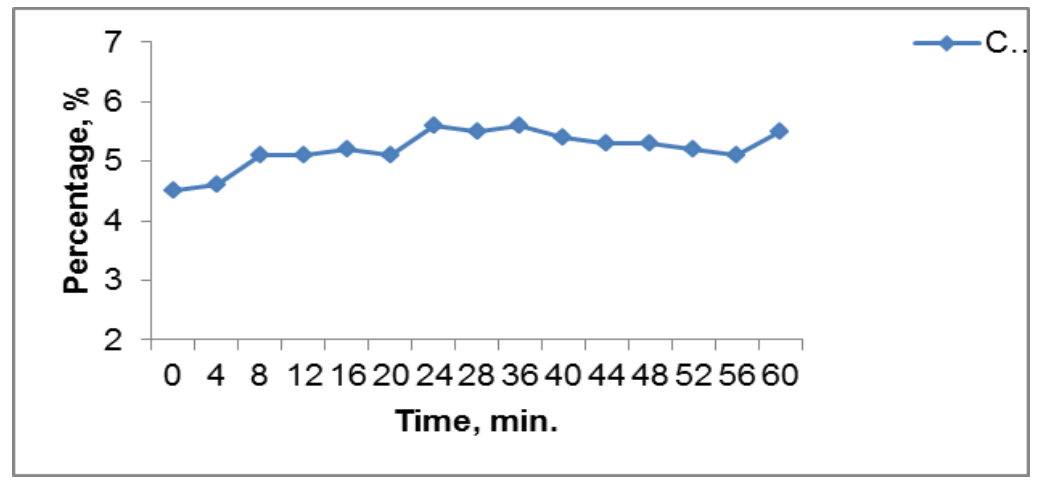

Burning rate and capacity (power output) of cook stove

The burning rate of the developed community cook stove has been worked out for the biomass feedstock selected in the experimentation. The burning rate of the cook stove mainly applicable with the heat required for the preparation of cook. The total heat requirement for the experiment was worked out to be $8076 \mathrm{kcal}$. The energy input / burning rate $(\mathrm{kg} / \mathrm{h})$ for the briquette was observed to be $2.5 \mathrm{~kg} / \mathrm{h}$ and for solid wood it was $3.03 \mathrm{~kg} / \mathrm{h}$ respectively. Table 5 showed that burning rate of solid wood is higher than the briquette fuel. The ash remaining during the experiment is depicted in table 5. The ash remaining in solid wood was recorded to be $4.82 \%$ and in briquette $6.5 \%$. The capacity of developed community cook stove has been determined on the feed rate of cook stove heating value of fuel used and the thermal efficiency. Table 5 showed the power rating output for briquette feed was observed to be $4.27 \mathrm{~kW}$ for energy input rate of $2.5 \mathrm{~kg} / \mathrm{h}$. Similarly the power output for solid wood was worked out for the energy input rate of 3.03 $\mathrm{kg} / \mathrm{h}$ and observed to be $4.69 \mathrm{~kW}$. The average power output of the community cook stove was found to be $4.48 \mathrm{~kW}$.

\section{Thermal efficiency of community cook stove}

The stove was basically developed for the higher thermal energy utilization. The fuels used for the evaluation was taken as briquette and the solid wood. The thermal efficiency of stove was evaluated as per the testing norms mentioned in BIS test code IS 13152 (Part 1). Thermal efficiency is the function to capture the heat generated by the stove after the burning of fuel. The thermal efficiency of the developed community cook stove has been compared with the stove available in the market. The thermal efficiency was found more than similar test 
carried out by Panwar et al., 2008 for $5 \mathrm{~kW}$ stove.

Thermal efficiency of the community cook stove for briquette is depicted in table 6. It is clear evidence that, the developed community cook stove, have more energy efficient than the market community cook stove. The thermal efficiency of the market community stove and developed community stove was observed to be $31.08 \%$ and $35.42 \%$ respectively. The developed community stove was found $12.25 \%$ more thermal efficient than the market community stove during testing for agro residue briquette.

The developed community cook stove has been tested for the various arrangements like with arrangement of top rest and without top rest. The top rest influences on the flame orientation to the vessel and thereby on the heat utilization. Table 7 showed the details of thermal efficiency of community cook stove for briquette and solid wood. It is found that, thermal efficiency of stove was $37.85 \%$ for briquettes and $35.16 \%$ for solid wood without top rest.

Table 8 depicted the results of efficiency for briquette with an adjustment of grate height. The grate height adjustment in the combustion chamber was at zero level at full loading of fuel and after the ignition as burning of fuel the grate height in the combustion chamber increased upto $7.5 \mathrm{~cm}$ and hence decreasing the combustion zone area. Table 8 showed the result obtain for the thermal efficiency of community cook stove for briquette fuel with top rest. The thermal efficiency for the grate height adjustment was found to be $35.42 \%$ and similarly for without height adjustment it was $33.23 \%$ (Figs 6 and 7).

\section{Emission evaluation smoke from community cook stove}

The smoke emission from the biomass cook stove is the major concern to human health and environment. The smoke content mainly $\mathrm{CO}_{2}$, $\mathrm{CO}, \mathrm{NO}_{\mathrm{x}}, \mathrm{SO}_{\mathrm{x}}, \mathrm{HC}$ which have adversely affects the environment of kitchen. The developed cook stove has been tested for the biomass feed stock viz. briquettes and solid wood. The smoke emission analysis was worked out for the one hour of combustion of briquette fuel in the community cook stove. The $\mathrm{NO}_{\mathrm{x}}$ and $\mathrm{SO}_{\mathrm{x}}$ emission from cook stove has been analyzed by using the gas analyser. The $\mathrm{SO}_{\mathrm{x}}$ emission during the test period was found 215 to $265 \mathrm{ppm}$. The trends of $\mathrm{NOx}$ and $\mathrm{SO}_{\mathrm{x}}$ emission from cook stove is depicted in figure 9 .

The emission of $\mathrm{CO}$ and $\mathrm{HC}$ from the cook stove was analysed for the same biomass sample. Figure 10 revealed that the content of $\mathrm{CO}$ in the smoke is in the average of $1129 \mathrm{ppm}$ to $1375 \mathrm{ppm}$ during the test period. The hydrocarbon (HC) content in the smoke shown in table 10 and it was in the range of $990 \mathrm{ppm}$ to $1203 \mathrm{ppm}$. The carbon dioxide emission from the burnt fuel during the test was reported to be $4.5 \%$ to $5.6 \%$ and approximately it was constant during the test period (Fig. 11).

The performance of developed cook stove was carried out as per the procedure specified in the BIS test code IS 13152 (Part 1). The thermal profile of the cook stove for the various temperature zones viz., outer temperature, flame temperature, exhaust air temperature was recorded during the experimentation. The burning rate of the developed cook stove was worked out for the briquettes and solid wood fuels. Based on the water boiling temperature during the experimentation and federate of fuel the thermal efficiency of cook stove was determined. The average power output of the community cook stove was found to be 4.48 $\mathrm{kW}$. The design of the community sized agro residue based briquetted cook stove of $4.48 \mathrm{~kW}$ rated capacity was found suitable for cooking the food for above 25 members in batch. The thermal efficiency of cook stove on burning briquettes was $37.54 \%$ found $6.33 \%$ more than solid wood fuel at the corresponding average flame temperature and burning rate of solid wood of $730.20 \mathrm{C}$ and $3.03 \mathrm{~kg} / \mathrm{h}$, respectively. Thermal efficiency of developed cook stove 
was found to be $12.25 \%$ higher than the locally available community cook stove of same size.

\section{References}

1. Anonymous. 2010. Final Report of New Initiative for Development and Deployment of Improved Cookstove: Recommended Action Plan. Ministry of Non-Conventional Energy Sources. Government of India.

2. Banarjee, P.K., Sharma, S.P. and Parikh, P.P. 1990. Design and Development of an Industrial Gas Burner for use with low energy gas. Proceedings of 2nd National Conference on Recent Advances in Biomass Gasification Technology, pp.312-317.

3. Belonio, Alexis T. and Anderson, Paul S. 2005. Rice Husk Gas Stove Handbook, Department of agricultural engineering and environmental management, college of agriculture, central Philippine University, Iloilo city, Philippines. $15-141$.

4. Bhattacharya, S. C. and Salam, P. A. 2002. Low greenhouse gas biomass options for cooking in the developing countries. Biomass and Bioenergy, 22(4): 305-17.

5. Bhattacharya, S.C., Attalage, R.A., Augustus, L.M., Amur, G.Q., Salam, P.A. and Thanawat, C. 1999. Potential of biomass fuel conservation in selected Asian countries. Energy Conversion and Management, 40(11): 1141-1162.

6. Birwatkar V. R., Khandetod Y. P., Mohod A. G. and Dhande K. G., 2014. Physical and Thermal Properties of Biomass Briquetted Fuel. Ind. J. Sci. Res. and Tech. 2014 2(4):5562.

7. Dubey, Anil and Gangil, Sandip. 2000. Coordinators Report. All India Coordinated Research Project on Renewable Sources of
Energy for Agriculture and agro-based Industries. Annual Workshop : 33-36.

8. Jittabuta P., 2015. Physical and Thermal Properties of Briquette Fuels from Rice Straw and Sugarcane Leaves by Mixing Molasses. ScienceDirect. Energy Procedia 79 ( 2015 ) 2 9

9. Khardiwar M.S., Dubey A.K., Mahalle D.M., Kumar S., 2014. Performance of Open Core Gasifier with Briquette of different Crop Residues. International Journal of Engineering Sciences \& Research Technology. 3(5) 833840.

10. Koopmans, A. and Heruela, C. 1999. Trends in Wood, Biomass and Other Energy Sources. Wood Energy News, 14(3):6.

11. Panwar, N.L., and Salvi, B. L. 2011. Experimental investigation of producer gas burner for thermal application. International Journal of Sustainable Energy, 30: 376-384.

12. Sharma, D. and Panwar, N.L. 2009. Performance evaluation of biomass based natural draft gasifier system for thermal application. Institution of Engineers (India) Journal-AG, 90: 34-38.

13. Tripathi, A. K.a, Iyer, V. R.a and Kandpal, T. C. 1999. Biomass gasifier based institutional cooking in India: a preliminary financial evaluation. Biomass and Bioenergy. 17(2):165-73.

14. Varunkumar, S., Rajan, N.K.S. and Mukunda, H. S. 2011. Experimental and computational studies on a gasifier based stove. Energy Conversion and Management, 53: 135-141..

15. Zanjani N. G., Moghaddam A. Z. and Dorosti S. 2014. Physical and Chemical Properties of Coal Briquettes from Biomass-Bituminous Blends. Petroleum \& Coal 56(2) 188-195.

\section{How to cite this article:}

Patil, S.R., S.R. Kalbande and Khambalkar, V.P. 2017. Feasibility Evaluation of Briquette Biomass Cook Stove for Rural Area. Int.J.Curr.Microbiol.App.Sci. 6(10): 3190-3203. doi: https://doi.org/10.20546/ijcmas.2017.610.374 